\title{
Pengaruh Kompetensi, Pemecahan Masalah, Kematangan Audit, Aktivitas Komputer Audit Terhadap Kinerja Audit Internal
}

\author{
Oei, Michelle Ignatia \\ Universitas Katolik Soegijapranata \\ michelleignatia6@gmail.com
}

\begin{abstract}
The purpose of this study is to examine the influence of competence, problem solving ability in team, audit maturity and computer audit activity on internal audit performance at company in Semarang. The population of this research is internal auditor of manufacturing company in Semarang City. The sample in this research is taken using purposive sampling method. The number of samples in this study were 49 respondents. Hypothesis testing of this research using SmartPLS 3. The result of this research: 1) Competence has positive effect on internal audit performance, 2) Problem solving ability in team does not positively affect to internal audit performance 3) Audit maturity has no positive effect on internal audit performance, 4) Audit computer activity has no positive effect on internal audit performance 5) Competence has no positive effect on internal audit performance through team problem solving ability, 6) Competence has no positive effect on internal audit performance through audit maturity, 7) Competence has no positive effect on the performance of internal audit through computer audit activities.
\end{abstract}

Keywords: competence, team problem solving skills, audit maturity, computer audit activities, internal audit performance

\begin{abstract}
Abstrak
Tujuan penelitian ini adalah menguji pengaruh kompetensi, kemampuan pemecahan masalah dalam tim, kematangan audit dan aktivitas komputer audit terhadap kinerja audit internal pada perusahaan di Semarang. Populasi penelitian ini adalah auditor internal perusahaan manufaktur di Kota Semarang. Sampel pada penelitian diambil menggunakan metode purposive sampling. Jumlah sampel pada penelitian ini yaitu 49 orang responden. Pengujian hipotesis penelitian ini menggunakan SmartPLS 3. Hasil dari penelitian ini: 1) Kompeensi berpengaruh positif terhadap kinerja audit internal, 2) Kemampuan pemecahan masalah dalam tim tidak berpengaruh positif terhadap kinerja audit internal, 3) Kematangan audit tidak berpengaruh positif terhadap kinerja audit internal, 4) Aktivitas komputer audit tidak berpengaruh positif terhadap kinerja audit internal, 5) Kompetensi tidak berpengaruh positif terhadap kinerja audit internal melalui kemampuan pemecahan masalah dalam tim, 6) Kompetensi tidak berpengaruh positif terhadap kinerja audit internal melalui kematangan audit, 7) Kompetensi tidak berpengaruh positif terhadap kinerja audit internal melalui aktivitas komputer audit.
\end{abstract}

Kata kunci: kompetensi, kemampuan pemecahan masalah dalam tim, kematangan audit, aktivitas komputer audit, kinerja audit internal 


\section{PENDAHULUAN}

Setiap negara berupaya mewujudkan masyarakat yang sejahtera melalui peran serta sektor bisnis untuk terus melakukan ekspansi sehingga pendapatan pajak negara meningkat dan tingkat pengangguran menurun. Agar terus bertumbuh perusahaan membutuhkan pendanaan eksternal untuk membiayai segenap aktivitas produksi, pemasaran, dan penjualan. Selain kredit perbankan, sumber pendanaan eksternal juga dapat dilakukan dengan menawarkan saham perusahaan kepada investor. Untuk mendapat sumber pendanaan eksternal, perusahaan harus mampu menampilkan kinerja keuangan yang baik sehingga investor berminat membeli saham perusahaan. Investor di luar perusahaan mengandalkan laporan keuangan yang diterbitkan secara berkala untuk menilai kinerja keuangan perusahaan. Hasil analisis menjadi dasar yang kuat bagi investor dalam menilai prospek perusahaan.

Selain ditujukan untuk pihak eksternal, laporan keuangan juga berguna bagi pihak internal sebagai input dalam mengembangkan strategi-strategi bisnis yang tepat dalam menghadapi persaingan dan juga dalam mengambil keputusan-keputusan penting yang menyangkut masa depan perusahaan. Namun harus disadari bahwa keputusan yang tepat membutuhkan laporan keuangan yang andal dan laporan keuangan yang andal membutuhkan kebijakan akuntansi yang sehat. Pemilihan kebijakan akuntansi yang sehat oleh perusahaan tidak terlepas dari peran serta auditor internal untuk memastikan prinsip-prinsip akuntansi yang sehat telah digunakan dalam penyusunan laporan keuangan. Berdasarkan pemikiran ini maka investigasi faktor-faktor yang dapat meningkatkan kinerja auditor internal sangat penting dilakukan.

Penelitian ini adalah replikasi penelitian $\mathrm{Wu}$ et al. (2016) yang mencoba mengidentifikasi determinan kinerja auditor internal. Hasil penelitian $\mathrm{Wu}$ et al. (2016) menunjukkan bahwa kompetensi tidak berpengaruh positif terhadap kinerja audit internal, namun kemampuan pemecahan masalah dalam tim dan aktivitas komputer audit berpengaruh positif terhadap kinerja audit internal. Mereka merekomendasikan penelitian berikutnya untuk menguji pengaruh kematangan audit internal dalam kinerja audit internal atau lebih mengeksplorasi kompetensi untuk meningkatkan kematangan audit internal. Sebagai respon atas rekomendasi tersebut, penelitian ini akan menguji pengaruh kompetensi, kemampuan pemecahan masalah dalam tim dan aktivitas komputer audit terhadap kinerja audit internal serta mengujai interaksi antara kemampuan pemecahan masalah dalam tim dan aktivitas komputer audit dalam meningkatkan kinerja auditor internal. Di samping itu, penelitian ini juga menambah variabel kematangan audit dengan mengambil sampel yang terdiri dari auditor internal perusahaan-perusahaan yang ada di Semarang.

\section{TINJAUAN LITERATUR DAN PERUMUSAN HIPOTESIS}

\section{Kinerja Audit Internal}

Audit merupakan suatu proses sistematis secara objektif memperoleh dan mengevaluasi suatu bukti terkait dengan pernyataan mengenai tindakan dari kegiatan ekonomi yang sesuai dengan kriteria yang telah ditentukan dan mengkomunikasikannya dengan pihak yang berkepentingan. Menurut Sujana (2012) teori ekspektansi pada dunia auditor menyatakan bahwa kinerja auditor merupakan fungsi bersama dari kemampuan dari seorang auditor dalam melakukan tugas, persepsi auditor terhadap kesesuaian peran yang dilakukan dan motivasi, artinya kinerja auditor akan maksimal apabila ditunjang oleh kemampuan dan keterampilan yang baik, adanya persepsi kesesuaian peran dan adanya motivasi yang tinggi. 
Teknnologi informasi telah menjadi sebuah kebutuhan pokok dalam kehidupan sehari hari, baik bagi individu maupun organisasi. Teknologi informasi (TI) memberikan kemudahan dalam setiap kegiatan, seperti contohnya transaksi. Menurut Wu et al. (2016) teknologi informasi dibagi menjadi 2 kategori, yaitu : kontrol dan aplikasi umum. Menurut $\mathrm{Wu}$ et al. (2016), kontrol umum bisa diterapkan ke semua sistem dan proses, termasuk database, sistem operasional, pengembangan sistem, dan perubahan program. Kontrol aplikasi digunakan untuk memastikan validitas, kelengkapan, dan keakuratan transaksi yang sesuai.

\section{Kompetensi}

Kompetensi adalah suatu yang mendasari karakteristik individu yang dihubungkan dengan hasil yang diperoleh dalam suatu pekerjaan (Economic, 2015). Kompetensi didukung oleh beberapa komponen seperti motif, sifat, konsep diri, pengetahuan dan kemampuan menurut $\mathrm{Wu}$ et al. (2016). Motif, ciri dan konsep diri adalah aspek kepribadian yang tidak mencolok dan sulit dibentuk hanya dengan sebuah latihan. Namun, pengetahuan dan kemampuan merupakan aspek kepribadian yang mencolok dan dapat dibentuk melalui pelatihan. Menurut Wu et al. (2016), hal terbesar yang mempengaruhi kinerja audit internal adalah kompetensi individu. Penelitian ini menggunakan model KSA dalam mengukur kompetensi yang terdiri dari pengetahuan, keterampilan dan kemampuan menurut $\mathrm{Wu}$ et al. (2016). Secara umum, model KSA terdiri dari pengetahuan, keterampilan dan kemampuan. Kemampuan itu direpresentasikan dengan menggunakan tugas self-efficacy dan komputer self-efficacy menurut Wu et al. (2016).

\section{Kemampuan Pemecahan Masalah dalam Tim}

Menurut teori perilaku pemecahan masalah oleh Wu et al. (2016) menyatakan bahwa pemecahan masalah terdiri dari beberapa proses, yaitu penemuan masalah, pengumpulan informasi, penemuan solusi dan melakukan evaluasi. Kemampuan pemecahan masalah dalam tim dapat digunakan untuk memastikan pengembangan proyek kualitas menurut $\mathrm{Wu}$ et al. (2016). Menurut Wu et al. (2016), sebuah kemampuan tim dalam memecahkan masalah untuk mengatasi perubahan, memecahkan masalah secara cepat dan fleksibel, serta sesuai dengan metode yang tepat dapat dilakukan untuk mencapai tujuan organisasi.

\section{Aktivitas Komputer Audit}

Wu et al. (2016) menggunakan siklus audit untuk mengukur aktivitas komputer audit. Dalam Global Technology Audit Guide (GTAG) 16, siklus audit dibagi kedalam beberapa tahapan, yaitu perencanaan, persiapan, pengujian dan peninjauan. Pada tahap perencanaan, Institute of Internal Audit (2011) memberikan saran untuk melakukan analisis risiko dalam korporasi operasional. Menurut Vasarhelyi et al. dalam Wu et al. (2016). menyatakan bahwa tim audit harus memahami proses operasional dan sistem informasi untuk dapat melakukan analis risiko. Pada tahapan persiapan dan pengujian, auditor internal perlu memahami data mana saja yang diperlukan untuk dijadikan sampel dan cara untuk mengambilan data. Pada tahap peninjauan, tim audit mengusulkan rekomendasi audit kepada manajer dan mengumpulkan bukti untuk dapat melakukan rekomendasi. Fungsi utama dari aktivitas komputer audit adalah untuk mempermudah tugas audit internal dengan tujuan untuk memastikan efisiensi pengendalian internal perusahaan.

\section{Kematangan Audit}

Kematangan audit atau sering disebut Audit Maturity akan memberikan penilaian terhadap kedewasaan proses dan kemampuan audit dan review terhadap perspektif kemampuan auditing, serta memberikan rekomendasi untuk dapat mencapai tingkat 
kematangan yang lebih tinggi. Model kematangan audit dapat dibagi menjadi beberapa tingkatan. Mengutiip Internal Audit Capability Model (IA-CM) yang dikelurkan The Institute of Internal Audit (IIA) membagi proses audit, Mermod dan Sungun (2013) menjelaskan proses audit dalam beberapa level.

1. Level 1 - Initial Ciri-ciri level ini adalah ad hoc dan tidak terstruktur, audit terbatas untuk ketaatan, output tergantung pada keahlian orang pada posisi tertentu, tidak menerapkan praktik profesional secara spesifik selain yang ditetapkan asosiasi profesional, pendanaan disetujui oleh manajemen sesuai yang diperlukan, tidak adanya infrastruktur, auditor di perlakukan sama seperti sebagian besar unit organisasi, tidak ada kapabilitas yang dibangun, tidak memiliki area proses kunci yang spesifik. Pada level ini internal auditor belum dapat memberikan jaminan atas proses tata kelola sesuai peraturan yang berlaku dan belum mampu mendeteksi terjadinya fraud. Internal auditor keberadaannya hanya sebatas kelembagaan, namun belum menunjukkan eksistensi.

2. Level 2 - Infrastructure Pada level ini internal audit sudah mengalami perkembangan baik pengembangan SDM internal audit, praktik (sudah mengarah berdasarkan kerangka kerja praktik profesional), audit pengelolaan organisasi internail audit (perencanaan dan penganggaran) serta pelasanaan audit sudah berbasis ketaatan. Pada tahap ini internal audit sudah mampu menjamin proses tata kelola sesuai dengan peraturan serta sudah mampu mendeteksi terjadinya fraud.

3. Level 3 - Integrated Pada level ini internal audit sudah menjadi mitra manajemen sebagai tempat layanan konsultasi. Dalam proses auditnya, juga tidak lagi berbasis audit ketaatan tetapi sudah berbasis audit kinerja/ evaluasi kinerja dan sudah mampu menilai efisiensi, efektivitas, ekonomis suatu kegiatan dan mampu memberikan konsultasi pada tata kelola, manajemen risiko, dan pengendalian intern

4. Level 4 - Managed Pada level ini, internal audit sudah mampu berkontribusi terhadap pengembangan manajemen dengan jaminan menyeluruh atas tata kelola, manajemen risiko, dan pengendalian organisasi.

5. Level 5 - Optimizing Level ini merupakan level tertinggi dari tingkat perkembangan internal audit. Pada level ini internal audit sudah menjelma sebagai organisasi sebagai agen perubahan yang tidak hanya berhubungan manajemen, tetapi sudah mampu berperan aktif dengan dunia luar organisasi.

\section{Kompetensi Dan Kinerja Audit Internal}

Kompetensi didukung oleh beberapa komponen seperti motif, sifat, konsep diri, pengetahuan dan kemampuan Wu et al. (2016). Motif, ciri dan konsep diri adalah aspek kepribadian yang tidak mencolok dan sulit dibentuk hanya dengan sebuah latihan. Namun, pengetahuan dan kemampuan merupakan aspek kepribadian yang mencolok dan dapat dibentuk melalui pelatihan. Menurut $\mathrm{Wu}$ et al. (2016), satu faktor yang mempengaruhi kinerja suatu pekerjaan adalah kompetensi dari para pekerja. Begitu pula dengan auditor internal, agar memperoleh tingkat kinerja yang baik maka dibutuhkan kompetensi dasar sebagai seorang auditor yang akan mendukung kinerjanya sebagai seorang auditor. Pada penelitian sebelumnya menunjukkan bahwa kompetensi berpengaruh secara signifikan terhadap kinerja Wu et al. (2016). Semakin luas kompetensi dasar yang dimiliki oleh responden maka semakin baik kinerja audit internal yang dilakukan responden dalam pekerjaannya. Pada penelitian ini mengusulkan hipotesis berikut :

\section{H1 : Kompetensi berpengaruh positif terhadap kinerja audit internal}




\section{Pemecahan Masalah dalam Tim dan Kinerja Audit Internal}

Masalah merupakan suatu hal yang harus diselesaikan dalam hal ini seorang auditor harus menyelesaikan masalah atau memecahkan masalah yang ada dalam sebuah tim. Menurut Wu et al. (2016) mengatakan bahwa kemampuan pemecahan masalah dalam tim dapat digunakan untuk memastikan perkembangan kualitas. Sebuah tim dapat menyelesaikan tujuannya dengan menggunakan kemampuan pemecahan masalah dalam tim dengan mencari metode tercepat menurut $\mathrm{Wu}$ et al. (2016). Semakin tinggi kemampuan pemecahan masalah dalam tim oleh responden maka semakin baik kinerja audit internal yang dilakukan oleh responden. Penelitian ini mengusulkan hipotesis sebagai berikut :

H2 : Kemampuan pemecahan masalah dalam tim berpengaruh positif terhadap kinerja audit internal

\section{Kematangan Audit dan Kinerja Audit Internal}

Model kematangan adalah untuk mengetahui pada tingkat mana auditor melakukan tugas dalam kegiatan audit dan menjadi alat untuk mengukur seberapa bagi proses audit yang berlangsung, Kematangan audit memiliki beberapa level atau tingkat kematangan yang sama dengan kematangan pada COBIT yang sering digunakan untuk mengukur kematangan pengelolaan TI dalam pengendalian internal. Model kematangan ini digunakan untuk mengukur seberapa efektif kinerja audit internal yang telah dilakukan oleh auditor internal. Semakin tinggi kemampuan responden dalam membawa perubahan bagi perusahaan maka semakin baik kinerja audit internal yang dilakukan oleh responden. Penelitian ini mengusulkan hipotesis sebagai berikut :

\section{H3 : Kematangan audit berpengaruh positif terhadap kinerja audit internal}

\section{Aktivitas Komputer Audit dan Kinerja Audit Internal}

Salah satu tujuan utama audit adalah untuk memstikan efisiensi dari pengendalian internal. Auditor internal dapat menggunakan komputer audit dalam melakukan proses audit pada sebuah perusahaan yang kebijakan auditnya dapat dikembangkan. Apabila pelaksanaan proses audit dengan menggunakan basis komputer terlaksana dengan baik dan sesuai dengan rencana dan menghasilkan hasil yang diharapkan, maka tim audit komputer sukses menjaga kualitas dan efisiensi audit mereka. Semakin tinggi kemampuan responden melakukan proses audit dengan menggunakan basis komputer maka semakin baik kinerja audit internal yang dilakukan oleh responden. Oleh karena itu, penelitian ini mengusulkan hipotesis sebagai berikut :

\section{H4 : Aktivitas komputer audit berpengaruh positif terhadap kinerja audit} internal

\section{Pengaruh Kompetensi Terhadap Kinerja Audit Internal dan Kemampuan Pemecahan Masalah dalam Tim}

Sebuah tim audit dituntut untuk dapat bekerja dalam tim dan pekerjaan tim audit adalah memecahkan masalah yang ada, hal tersebut harus didukung - dengan kompetensi dari masing - masing individu dalam tim. Menurut $\mathrm{Wu}$ et al. (2016) mengatakan bahwa kemampuan pemecahan masalah dalam tim merupakan salah satu kompetensi yang membantu tim dalam menangani perubahan sikap dan untuk mencapai tujuan tim yang lebih baik. Menurut $\mathrm{Wu}$ et al. (2016) mengatakan bahwa kompetensi individu dinilai sangat penting untuk peningkatan efisiensi kinerja tim dalam mencapai tujuan tim. Hubungan antara kompetensi dan kemampuan pemecahan masalah sangatlah berkaitan satu sama lain. Kompetensi yang dimiliki oleh individu dapat menunjang kemampuan sebuah tim untuk melakukan pemecahan masalah seperti ketepatan waktu pencarian informasi, inovasi, dan pelaksanaan tugas kelompok menurut $\mathrm{Wu}$ et al. (2016). Semakin tinggi kompetensi 
responden memberi kontribusi akan kemampuan pemecahan masalah dalam tim maka semakin baik kinerja audit internal yang dilakukan responden. Dengan adanya hubungan antara kedua variabel tersebut, maka dalam penelitian ini mengusulkan hipotesis sebagai berikut :

\section{H5 : Kompetensi berpengaruh positif terhadap kinerja audit internal melalui kemampuan pemecahan masalah dalam tim}

\section{Pengaruh Kompetensi terhadap Kinerja Audit Internal dan Kematangan Audit}

Kompetensi sangat diperlukan dalam penilaian kematangan audit. Auditor perlu untuk mengetahui informasi apa saja yang diperoleh dalam kegiatan audit yang dilakukan dengan kompetensi yang dimiliki. Apabila auditor memahami proses audit yang dijalankan, maka dapat dilakukan penilaian akan kinerja audit internal yang ada. Semakin tinggi kompetensi responden memberi kontribusi akan kematangan audit dalam proses audit maka semakin baik kinerja audit internal yang dilakukan responden. Oleh karena itu, penelitian ini mengusulkan hipotesis sebagai berikut :

\section{H6 : Kompetensi berpengaruh positif terhadap kinerja audit internal melalui kematangan audit}

\section{Pengaruh Kompetensi terhadap Kinerja Audit Internal melalui Aktivitas Komputer Audit}

Menurut $\mathrm{Wu}$ et al. (2016) pengetahuan yang rendah membatasi ruang lingkup komputer audit. Kompetensi berkaitan dengan penggunaan alat analisis data, TI, pengendalian internal dan metode audit yang digunakan. Kompetensi sangat dibutuhkan untuk melakukan aktivitas komputer audit dengan melakukan analisis data yang tepat dan menetapkan audit otomatis yang lengkap dan komprehensif. Semakin tinggi kompetensi responden memberi kontribusi akan pelaksanaan proses audit menggunakan basis komputer maka semakin efektif kinerja audit internal yang dilakukan responden. Penelitian ini mengusulkan hipotesis sebagai berikut

\section{H7 : Kompetensi berpengaruh positif terhadap kinerja audit internal melalui aktivitas komputer audit}

\section{METODA PENELITIAN}

\section{Populasi dan Sampel}

Populasi yang akan digunakan dalam penelitian ini adalah seluruh auditor internal pada perusahaan manufaktur di Kota Semarang. BPS tahun 2014 mencatat ada 126 perusahaan manufaktur tergolong sedang besar di Semarang. Teknik pengambilan sampel adalah dengan purposive sampling. Sampel yang diambil memiliki maksud atau tujuan tertentu. Pengambilan sampel dari populasi berdasarkan kriteria tertentu. Kriteria sampel yang diambil yaitu :

1. Auditor internal yang bekerja pada perusahaan di Semarang

2. Auditor yang bersedia mengisi kuesioner

3. Auditor internal yang bekerja pada perusahaan yang memiliki tim audit atau dengan kata lain perusahaan memiliki lebih dari 1 orang auditor.

Berdasarkan kriteria di atas, tersedia sebanyak 49 responden tersedia dan dapat digunakan untuk pengujian hopotesis. 


\section{Sumber Data}

Jenis data yang diambil adalah data primer dan sumber data adalah dari responden secara langsung melalui pertanyaan. Peneliti mengantarkan kuesioner langsung ke alamat responden dan pengambilan kuesioner juga diambil langsung oleh peneliti sesuai dengan janji yang dibuat dengan responden. Pengumpulan data dalam penelitian ini akan menggunakan kuesioner. Kuesioner yang berisikan pertanyaan - pertanyaan mengenai variabel - variabel yang diuji oleh peneliti dan juga berisikan identitas dari responden yang gunanya agar tidak terjadi kesamaan data yang telah diinput.

\section{Definisi dan Pengukuran Variabel}

\section{Kompetensi}

Kompetensi adalah presepsi responden karakteristik yang dimiliki oleh responden dan kemampuannya menggunakan cara yang tepat untuk mencapai kinerja yang diinginkan melalui keluasan pengetahuan, keterampilan mengolah berbagai informasi yang didapatkan dengan cara berpikir logis, berinteraksi dengan sesama, melakukan evaluasi kerja dan independen terhadap rekan kerjanya., memahami fungsi internal audit dalam proses audit diperusahaan sesuai dengan kebijakan yang ada dan melakukan proses audit berbasis komputer. Unsur pengetahuan memiliki 5 pertanyaan tentang seberapa luas pemahaman auditor internal akan dasar dari proses audit, ERP, keamanan informasi database, CAAT dan manajemen risiko. Kuesioner ini terdapat dalam penelitian sebelumnya, yaitu dari Wu et al. (2016). Pengukuran terhadap variabel ini menggunakan skala likert dengan 5 skala likert. Skor 5 = Sangat Setuju, skor $4=$ Setuju, skor $3=$ Netral, skor $2=$ Tidak Setuju, dan skor $1=$ Sangat Tidak Setuju. Semakin tinggi skor, maka semakin tinggi pula kompetensi.

\section{Kemampuan Pemecahan Masalah dalam Tim}

Masalah merupakan suatu hal yang harus diselesaikan dalam hal ini seorang auditor harus menyelesaikan masalah atau memecahkan masalah yang ada dalam sebuah tim. Menurut $\mathrm{Wu}$ et al. (2016) mengatakan bahwa kemampuan pemecahan masalah dalam tim dapat digunakan untuk memastikan perkembangan kualitas. Variabel ini memiliki 12 pertanyaan mengenai presepsi auditor internal yang tentang kemampuan rekan kerja, efisiensi kinerja tim dan kenyamanan responden dengan rekan kerja dalam tim. Kuesioner ini terdapat dalam penelitian sebelumnya, yaitu dari Wu et al. (2016). Pengukuran terhadap variabel ini menggunakan skala likert dengan 5 skala likert. Skor $5=$ Sangat Setuju, skor $4=$ Setuju, skor $3=$ Netral, skor $2=$ Tidak Setuju, dan skor $1=$ Sangat Tidak Setuju. Jika semakin tinggi skor yang diberikan, maka semakin tinggi penilaian responden terhadap kemampuan rekan kerja, efisiensi kinerja tim dan kenyamanan responden dengan rekan kerja dalam tim.

\section{Kematangan Audit}

Variabel ini memiliki 17 pertanyaan mengenai presepsi auditor internal tentang kemampuannya dalam berinvestasi strategis, mengefektifkan operasional, merencanakan audit sesuai visi, dan pemahaman audit dan auditee. Pengukuran terhadap variabel ini menggunakan skala likert dengan 5 skala likert. Skor 5 = Sangat Setuju, skor $4=$ Setuju, skor 3 = Netral, skor 2 = Tidak Setuju, dan skor 1 = Sangat Tidak Setuju. Jika semakin tinggi skor yang diberikan, maka semakin tinggi responden berinvestasi strategis, operasional yang efektif, melakukan proses audit sesuai visi, dan tingkat pemahaman akan audit dan auditee yang tinggi. 


\section{Aktivitas Komputer Audit}

Variabel ini memiliki 12 pertanyaan mengenai presepsi responden tentang kemampuannya mengidentifikasi kegiatan komputer audit, tujuan audit, identifikasi kelemahan dan penyebab penipuan. Kuesioner ini terdapat dalam penelitian sebelumnya, yaitu dari $\mathrm{Wu}$ et al. (2016). Pengukuran terhadap variabel ini menggunakan skala likert dengan 5 skala likert. Skor $5=$ Sangat Setuju, skor $4=$ Setuju, skor $3=$ Netral, skor $2=$ Tidak Setuju, dan skor 1 = Sangat Tidak Setuju. Jika semakin tinggi skor yang diberikan, maka semakin tinggi pengetahuan dan kemampuan dalam melaksanakan proses audit yang sesuai dengan tujuan audit dan mampu mengidentifikasi kelemahan dan penyebab penipuan dengan baik.

\section{Kinerja Audit Internal}

Variabel ini memiliki 5 pertanyaan mengenai presepsi auditor internal tentang efisiensi operasi. Kuesioner ini terdapat dalam penelitian sebelumnya, yaitu dari Wu et al. (2016). Pengukuran terhadap variabel ini menggunakan skala likert dengan 5 skala likert. Skor $5=$ Sangat Setuju, skor $4=$ Setuju, skor $3=$ Netral, skor $2=$ Tidak Setuju, dan skor $1=$ Sangat Tidak Setuju. Jika semakin tinggi skor yang diberikan, maka operasi dalam perusahaan semakin efisien.

\section{HASIL DAN PEMBAHASAN}

\section{Gambaran Umum Responden}

Penelitian ini dilakukan pada Auditor Internal pada Perusahaan di Semarang. Kuesioner yang disebar sebanyak 156 kuesioner dan sebanyak 49 kuesioner yang dapat dianalisis lebih lanjut. Tabel 4.1, tabel 4.2, dan tabel 4.3 memberikan gambaran tentang karakteristik responden.

Berdasarkan tabel 4.1 diatas, dapat diketahui bahwa responden dalam penelitian ini terdapat 26 orang berjenis kelamin laki - laki atau 53,06\% dan 23 orang berjenis kelamin perempuan atau 46,94\%. Artinya, responden dalam penelitian ini didominasi oleh pria.

Tabel 4.1. Karakteristik Responden $(n=49)$

\begin{tabular}{|c|c|c|}
\hline Jenis Kelamin & Jumlah & $\%$ \\
\hline Laki - laki & 26 & 53,06 \\
\hline Perempuan & 23 & 46,94 \\
\hline Total & 49 & 100 \\
\hline
\end{tabular}

Sumber : Data primer diolah

Berdasarkan tabel 4.2 dapat diketahui bahwa pada penelitian ini responden yang berpendidikan D3 berjumlah 1 orang (2,04\%), berpendidikan S1 berjumlah 38 orang $(77,55$ $\%$ ), yang berpendidikan S2 berjumlah10 orang (20,41\%), dan yang berpendidikan S3 berjumlah 0 orang $(0 \%)$. Artinya, responden dalam penelitian ini lebih banyak yang berpendidikan terakhir $\mathrm{S} 1$.

Tabel 4.2. Pendidikan Responden $(n=49)$

\begin{tabular}{|c|c|c|}
\hline Pendidikan & Jumlah & $\%$ \\
\hline D3 & 1 & 2,04 \\
\hline S1 & 38 & 77,55 \\
\hline S2 & 10 & 20,41 \\
\hline S3 & 0 & 0 \\
\hline Total & 49 & 100 \\
\hline
\end{tabular}

Sumber : Data primer diolah 
Berdasarkan tabel 4.3, diketahui bahwa responden yang berada pada posisisebagai staff auditor terdapat 1 orang (2,04\%), sebagai auditor junior terdapat 23 orang $(46,94 \%)$, sedangkan yang berada pada posisi sebagai auditor senior terdapat 19 orang $(8,78 \%)$ dan yang berada pada posisi sebagai kepala auditor terdapat 6 orang (12,24\%). Artinya, responden dalam penelitian ini lebih banyak yang berada pada posisi auditor junior.

Tabel 4.3. Jabatan $(n=49)$

\begin{tabular}{|l|c|c|}
\hline \multicolumn{1}{|c|}{ Jabatan } & Jumlah & \% \\
\hline Staff Auditor & 1 & 2,04 \\
\hline Auditor Junior & 23 & 46,94 \\
\hline Auditor Senior & 19 & 38,78 \\
\hline Kepala Auditor & 6 & 12,24 \\
\hline Total & 49 & 100 \\
\hline
\end{tabular}

Sumber : Data primer diolah

\section{Hasil Uji Validitas dan Reliabilitas}

Uji validitas digunakan untuk mengukur seberapa besar kuesioner dapat digunakan untuk mengukur masing-masing variabel dalam penelitian ini. Pengujian validitas data dilakukan dengan membandingkan nilai Cronbach Alpha If Item Deleted (CAIID) dan nilai Cronbach Alpha (CA). Jika nilai Cronbach Alpha If Item Deleted lebih kecil daripada nilai Cronbach Alpha, maka item dikatakan valid. Sebaliknya, jika nilai Cronbach Alpha If Item Deleted lebih besar daripada nilai Cronbach Alpha, maka item dikatakan tidak valid. Pengujian validitas dilakukan terhadap masing-masing variabel dan hasil pengujian menunjukkan seluruh item-item yang digunakan untuk mengukur variabel-variabel penelitian valid.

Pengujian reliabilitas digunakan untuk mengukur konsistensi atau ketetapan data. Berikut hasil pengujian reliabilitas data. Dari hasil pengujian diketahui bahwa nilai Cronbach Alpha variabel Kompetensi - Keterampilan sebesar 0,685, dan Tugas Self Efficacy sebesar 0,681, sehingga masing-masing menunjukkan reliabilitas moderat. Variabel Kompetensi Pengetahuan memiliki nilai Cronbach Alpha sebesar 0,737, Komputer Self Efficacy sebesar 0,825, Kemampuan Pemecahan Masalah dalam Tim sebesar 0,877, Aktivitas Komputer Audit sebesar 0,868, Kematangan Audit sebesar 0,895 dan Kinerja Audit Internal (KAI) sebesar 0,713, sehingga masing - masing menunjukkan reliabilitas tinggi. Dapat disimpulkan bahwa semua pernyataan reliabel.

\section{Analisis Statistik Deskriptif}

Berikut ini dapat dilihat tabel 4.4 yang menunjukkan nilai perbedaan rata-rata (compare means) dari masing-masing variabel dalam penelitian ini dengan jenis kelamin, usia, pendidikan akhir dan jabatan responden. Berdasarkan tabel 4.4 dapat diketahui bahwa variabel Kompetensi yang dinilai melalui Pengetahuan (P), Keterampilan (K), Tugas Self Efficacy (T) dan Komputer Self Efficacy (KS) dengan jenis kelamin, usia, pendidikan dan jabatan dapat diketahui bahwa tidak dapat perbedaan persepsi tentang kinerja audit internal. Hal ini dapat dilihat dari nilai signifikan yang lebih besar dari 0,05 , yaitu nilai signifikan dengan jenis kelamin sebesar 0,309 (P), 0,951 (K), 0,615 (T) dan 0,092 (KS). Nilai signifikan dengan usia sebesar 0,639 (P), 0,915 (K), 0,911 (T) dan 0,417 (KS). Nilai signifikan dengan pendidikan akhir sebesar 0,204 (P), 0,059 (K), 0,212 (T) dan 0,384 (KS). Nilai signifikan 
dengan jabatan sebesar 0,485 (P), 0,182 (K), 0,255 (T) dan 0,515 (KS). Hal ini menunjukkan responden menilai bahwa responden sama-sama setuju bila memiliki pengetahuan yang luas, keterampilan dalam mengolah informasi yang tinggi, memahami fungsi audit dalam proses audit dengan baik dan mampu melakukan proses audit dengan menggunakan komputer dengan baik dapat mempengaruhi peningkatan kinerja audit internal menjadi lebih baik.

Variabel Kemampuan Pemecahan Masalah dalam Tim (KP) dengan jenis kelamin, usia, pendidikan dan jabatan dapat diketahui bahwa tidak dapat perbedaan persepsi tentang kinerja audit internal. Hal ini dapat dilihat dari nilai signifikan yang lebih besar dari 0,05 . Nilai signifikan variabel kemampuan pemecahan masalah dalam tim (KP) dengan jenis kelamin sebesar 0,092, usia sebesar 0,341, pendidikan akhir sebesar 0,085 dan jabatan sebesar 0,235. Hal ini menunjukkan responden menilai bahwa responden sama-sama tidak setuju bila responden telah melakukan proses audit sesuai visi, dan tingkat pemahaman akan audit dan auditee tinggi akan mempengaruhi peningkatan kinerja audit internal menjadi lebih baik.

Variabel Aktivitas Komputer Audit (AK) dengan jenis kelamin, usia, pendidikan dan jabatan dapat diketahui bahwa tidak dapat perbedaan persepsi tentang kinerja audit internal. Hal ini dapat dilihat dari nilai signifikan yang lebih besar dari 0,05 . Nilai signifikan variabel aktivitas komputer audit (AK) dengan jenis kelamin sebesar 0,770, usia sebesar 0,469, pendidikan akhir sebesar 0,606 dan jabatan sebesar 0,613. Hal ini menunjukkan responden menilai bahwa responden sama-sama tidak setuju bila memiliki pengetahuan yang luas dan kemampuan dalam melaksanakan proses audit yang sesuai dengan tujuan audit dan mampu mengidentifikasi kelemahan dan penyebab penipuan dengan baik akan mempengaruhi peningkatan kinerja audit internal menjadi lebih baik.

Variabel Kematangan Audit (KA) dengan jenis kelamin, usia, pendidikan dan jabatan dapat diketahui bahwa tidak dapat perbedaan persepsi tentang kinerja audit internal. Hal ini dapat dilihat dari nilai signifikan yang lebih besar dari 0,05 . Nilai signifikan variabel kematangan audit (KA) dengan jenis kelamin sebesar 0,492, usia sebesar 0,607, pendidikan akhir sebesar 0,263 dan jabatan sebesar 0,422. Hal ini menunjukkan responden menilai bahwa responden sama-sama tidak setuju bila memiliki operasional telah efektif, melakukan proses audit sesuai visi, dan tingkat pemahaman akan audit dan auditee yang tinggi akan mempengaruhi peningkatan kinerja audit internal menjadi lebih baik.

Berdasarkan tabel 4.13 dapat diketahui bahwa variabel Kinerja Audit Internal (KAI) dengan jenis kelamin, usia, pendidikan dan jabatan dapat diketahui bahwa tidak dapat perbedaan persepsi tentang kinerja audit internal. Hal ini dapat dilihat dari nilai signifikan yang lebih besar dari 0,05 . Nilai signifikan variabel kinerja audit internal (KAI) dengan jenis kelamin sebesar 0,653, usia sebesar 0,133 , pendidikan akhir sebesar 0,708 dan jabatan sebesar 0,922. Hal ini menunjukkan responden menilai bahwa responden sama-sama tidak setuju bila operasional dalam perusahaan sudah efisien maka kinerja audit internal semakin baik. 


\section{Tabel 4.4. Compare Means}

\begin{tabular}{|c|c|c|c|c|c|c|c|c|c|c|c|c|c|c|c|c|c|}
\hline \multirow{2}{*}{ Keterangan } & \multirow{2}{*}{ Jumlah } & \multicolumn{2}{|c|}{$\mathrm{P}$} & \multicolumn{2}{|c|}{$\mathrm{K}$} & \multicolumn{2}{|c|}{$\mathrm{T}$} & \multicolumn{2}{|c|}{$\mathrm{KS}$} & \multicolumn{2}{|c|}{$\mathrm{KP}$} & \multicolumn{2}{|c|}{$\mathrm{AK}$} & \multicolumn{2}{|r|}{ KA } & \multicolumn{2}{|c|}{ KAI } \\
\hline & & Mean & Sig. & Mean & Sig. & Mean & Sig. & Mean & Sig. & Mean & Sig. & Mean & Sig. & Mean & Sig. & Mean & Sig. \\
\hline \multicolumn{18}{|c|}{ Jenis Kelamin: } \\
\hline Laki-laki & 26 & 4.3615 & \multirow{2}{*}{0.309} & 4.3154 & \multirow{2}{*}{0.951} & 4.4038 & \multirow{2}{*}{0.615} & 4.2923 & \multirow{2}{*}{0.626} & 4.3654 & \multirow{2}{*}{0.092} & 4.3154 & \multirow{2}{*}{0.770} & 4.2308 & \multirow{2}{*}{0.492} & 4.4769 & \multirow{2}{*}{0.653} \\
\hline Perempuan & 23 & 4.2261 & & 4.3087 & & 4.4585 & & 4.2304 & & 4.2261 & & 4.2826 & & 4.1522 & & 4.4261 & \\
\hline \multicolumn{18}{|l|}{ Usia: } \\
\hline $20-35$ & 29 & 4.2643 & \multirow{3}{*}{0.639} & 4.2929 & \multirow{3}{*}{0.915} & 4.4286 & \multirow{3}{*}{0.911} & 4.2643 & \multirow{3}{*}{0.417} & 4.2929 & \multirow{3}{*}{0.341} & 4.3357 & \multirow{3}{*}{0.469} & 4.1929 & \multirow{3}{*}{0.607} & 4.3714 & \multirow{3}{*}{0.133} \\
\hline $36-50$ & 16 & 4.3059 & & 4.3412 & & 4.4118 & & 4.2 & & 4.2647 & & 4.2118 & & 4.1529 & & 4.5176 & \\
\hline $51-65$ & 4 & 4.5 & & 4.3250 & & 4.5 & & 4.525 & & 4.5 & & 4.425 & & 4.375 & & 4.75 & \\
\hline \multicolumn{18}{|l|}{ Pendidikan: } \\
\hline D3 & 1 & 3.6 & \multirow{3}{*}{0.204} & 3.6 & \multirow{3}{*}{0.059} & 3.8 & & 3.8 & & 4 & & 4.1 & & 3.7 & & 4.2 & \\
\hline S1 & 38 & 4.285 & & 4.295 & & 4.4375 & 0.212 & 4.2475 & 0.384 & 4.27 & 0.085 & 4.2825 & 0.606 & 4.1775 & 0.263 & 4.445 & 0.708 \\
\hline S2 & 10 & 4.5 & & 4.4875 & & 4.4625 & & 4.4 & & 4.4875 & & 4.4125 & & 4.3375 & & 4.425 & \\
\hline Jabatan: & & & & & & & & & & & & & & & & & \\
\hline Staff & 1 & 3.6 & & 3.6 & & 3.8 & & 3.8 & & 4 & & 4.1 & & 3.7 & & 4.2 & \\
\hline Junior & 23 & 4.3217 & 0 & 4.2739 & 0 & 4.4957 & & 4.2826 & 0 & 4.2913 & & 4.3348 & & 4.2261 & & 4.4522 & \\
\hline Senior & 19 & 4.3842 & 0.485 & 4.3579 & 0.182 & 4.3895 & 0.255 & 4.2105 & 0.515 & 4.2632 & 0.235 & 4.2263 & 0.613 & 4.1368 & 0.422 & 4.4526 & 0.922 \\
\hline Kepala & 6 & 4.3667 & & 4.4333 & & 4.4 & & 4.4333 & & 4.5 & & 4.4333 & & 4.3333 & & 4.5 & \\
\hline
\end{tabular}




\section{Hasil Uji Hipotesis}

Penelitian ini menggunakan SmartPLS 3 untuk melakukan pengujian hipotesis. Pengujian ini menggunakan model struktural path coefficients untuk memprediksi hubungan antar variabel yang diuji. Pengujian ini melakukan pengukuran dengan melakukan perbandingan antara $t$-table dan $t$-statistics. Tingkat keyakinan yang digunakan adalah $95 \%$ dengan tingkat kesalahan yang diinginkan 5\%. Apabila nilai signifikansinya $>1,96$ maka hipotesis diterima.

\section{Tabel 4.5. Hasil Uji Hipotesis}

\begin{tabular}{|c|c|c|c|c|c|c|}
\hline & & $\begin{array}{c}\text { Original } \\
\text { Sample (O) }\end{array}$ & $\begin{array}{c}\text { Sample } \\
\text { Mean (M) }\end{array}$ & $\begin{array}{c}\text { Standard } \\
\text { Deviation }\end{array}$ & $\begin{array}{c}T \\
\text { Statistics }\end{array}$ & P Value \\
\hline $\mathrm{H} 1$ & $\begin{array}{c}\text { Kompetensi -> } \\
\text { Kinerja }\end{array}$ & 0,647 & 0,623 & 0,188 & 3,442 & 0,00 \\
\hline $\mathrm{H} 2$ & $\begin{array}{c}\text { Kemampuan } \\
\text { Pemecahan -> } \\
\text { Kinerja }\end{array}$ & 0,029 & 0,080 & 0,183 & 0,156 & 0,88 \\
\hline $\mathrm{H} 3$ & $\begin{array}{c}\text { Kematangan -> } \\
\text { Kinerja }\end{array}$ & $-0,006$ & $-0,005$ & 0,155 & 0,036 & 0,97 \\
\hline $\mathrm{H} 4$ & $\begin{array}{c}\text { Kktivitas } \\
\text { Komputer -> } \\
\text { Kinerja }\end{array}$ & 0,094 & 0,094 & 0,162 & 0,577 & 0,56 \\
\hline
\end{tabular}

Sumber : Data primer diolah

Dari tabel 4.5 diatas kita dapat melihat bahwa :

a. T-statistik $(3,442)>$ t-tabel 1,96 . Hal ini berarti Ha diterima, maka hipotesis 1 yaitu terdapat pengaruh positif antara kompetensi dengan kinerja audit internal diterima karena t-statistik > t-tabel.

b. T-statistik $(0,156)<1.96$. Hal ini berarti Ha ditolak dan H0 diterima, maka hipotesis 3 yaitu tidak terdapat pengaruh positif antara kemampuan pemecahan masalah dalam tim dengan kinerja audit internal.

c. T-statistik $(0,036)<1.96$. Hal ini berarti Ha ditolak dan H0 diterima, maka hipotesis 3 yaitu tidak terdapat pengaruh positif antara kematangan audit dengan kinerja audit internal.

d. T-statistik $(0,577)<$ t-tabel 1.96. Hal ini menunjukan bahwa Ha ditolak dan H0 diterima maka hipotesis 4 yaitu tidak terdapat pengaruh positif antara aktivitas komputer audit dengan kinerja audit internal

\section{PEMBAHASAN}

Hipotesis 1 berbunyi bahwa hipotesis diterima atau terdapat pengaruh positif antara kompetensi terhadap kinerja audit internal. Hal ini sama seperti pendapat dari $\mathrm{Wu}$ et al. (2016) yang mengatakan bahwa kompetensi adalah hal terbesar yang mempengaruhi kinerja audit internal. Beberapa komponen dari kompetensi sendiri ada yang dapat dibentuk melalui pelatihan seperti pengetahuan dan keterampilan. Dalam meningkatkan kinerjanya sebagai seorang auditor, diperlukan beberapa pengetahuan dasar sebagai seorang auditor untuk dapat 
mengolah data dan bukti-bukti dalam menjalankan tugasnya sebagai seorang auditor yang tentunya hal tersebut menunjang peningkatan kinerja sebagai seorang auditor.

Hipotesis 2 berbunyi bahwa kemampuan pemecahan masalah dalam tim tidak berpengaruh positif terhadap kinerja audit internal. Alasan penolakan hipotesis ini adalah kurangnya kerjasama dalam tim audit dengan kurangnya kepercayaan akan rekan kerja satu tim. Sebuah tim terdiri dari individu - individu yang memiliki kemampuan atau kompetensi masing - masing, oleh karena itu menurut Fitriastuti (2013) mengatakan bahwa kecerdasan emosional menyumbang $80 \%$ dari faktor penentu kesuksesan sesorang, sedangkan $20 \%$ yang lain ditentukan oleh IQ (Intelligence Quotient). Kecerdasan sosial adalah kemampuan memahami dan mengatur orang lain untuk bertindak bijaksana dalam menjalin hubungan, yang meliputi kecerdasan interpersonal dan kecerdasan intrapersonal. Kecerdasan interpersonal adalah kecerdasan untuk memahami orang lain, sedangkan kecerdasan intrapersonal adalah kemampuan mengelola diri sendiri menurut Fitriastuti (2013). Menurut Wong dalam Fitriastuti (2013) mengatakan bahwa orang yang memiliki kecerdasan emosi tinggi akan mampu memahami dirinya sendiri dan emosi orang lain. Orang tersebut dapat memanfaatkan pemahaman ini untuk meningkatkan perilaku dan sikapnya dalam menuju arah yang lebih positif, sehingga mampu mengendalikan emosi, lebih termotivasi, merasa puas dan mampu mengatasi masalah dengan lingkungan kerja serta kehidupannya. Kecerdasan emosi sangat mempengaruhi kerjasama yang dilakukan dalam tim. Pentingnya menurut Johnson dalam Fauzi (2012) kerjasama dapat menghilangkan hambatan mental akibat terbatasnya pengalaman dan cara pandang yang sempit, sehingga memungkinkan untuk menemukan kekuatan dan kelemahan diri, belajar menghargai orang lain, mendengarkan dengan pikiran terbuka, dan membangun persetujuan bersama. Penelitian ini membuktikan bahwa kemampuan pemecahan masalah dalam tim tidak terbukti secara empiris berpengaruh terhadap kinerja audit internal.

Hipotesis 3 berbunyi bahwa kematangan audit tidak berpengaruh positif terhadap kinerja audit internal atau hipotesis ditolak. Kematangan audit digunakan untuk mengukur sejauh mana peran seorang auditor dalam peningkatan efektivitas dan efisiensi kinerja audit internal. Variabel ini merupakan variabel baru yang direkomendasikan pada penelitian sebelumnya. Alasan penolakan hipotesis ini adalah kurangnya pandangan objektif responden terhadap kasus khusus, presepsi responden tentang kurangnya transisi dari pelestarian nilai ke nilai penciptaan, dan penciptaan portofolio layanan kepatuhan. Menurut Asy',M.A. et al. (2014) kesuluruhan proses penilaian kematangan audit adalah dengan analisa dan studi lapangan proses audit dan penentuan kontrol objektif proses teknologi informasi.

Hipotesis 4 berbunyi bahwa aktivitas komputer audit tidak berpengaruh positif terhadap kinerja audit internal, hipotesis ditolak. Alasan penolakan hipotesis ini adalah kurang lengkapnya penilaian risiko yang terkait dengan proses operasi kunci, kurangnya audit komputer yang mengkonfirmasi kelengkapan data elektronik dan belum terdapat audit komputer secara otomatis. Menurut Suginam (2016) mengatakan bahwa auditor harus waspada terhadap penipuan dan mengambil langkah segera untuk menginvestigasi kecurigaannya. Audit internal menyediakan jasa seperti pemeriksaan, penilaian kontrol, kinerja, risiko dan tata kelola. Menurut Wu et al. (2016) teknologi informasi dibagi menjadi 2 kategori, yaitu : kontrol dan aplikasi umum. Menurut Wu et al. (2016), kontrol umum bisa diterapkan ke semua sistem dan proses, termasuk database, sistem operasional, pengembangan sistem, dan perubahan program. Kontrol aplikasi digunakan untuk memastikan validitas, kelengkapan, dan keakuratan transaksi yang sesuai. 
Hipotesis 5 mengatakan bahwa kompetensi tidak berpengaruh positif terhadap kinerja audit internal melalui kemampuan pemecahan masalah dalam tim, hipotesis ditolak. Alasan penolakan hipotesis ini adalah kurangnya kerjasama dalam tim audit tentang kepercayaan akan rekan kerja satu tim. Sebuah tim terdiri dari individu - individu yang memiliki kemampuan atau kompetensi masing - masing, oleh karena itu menurut Fitriastuti (2013) mengatakan bahwa kecerdasan emosional menyumbang $80 \%$ dari faktor penentu kesuksesan sesorang, sedangkan 20\% yang lain ditentukan oleh IQ (Intelligence Quotient). Kecerdasan interpersonal adalah kecerdasan untuk memahami orang lain, sedangkan kecerdasan intrapersonal adalah kemampuan mengelola diri sendiri Fitriastuti (2013). Menurut Fitriastuti (2013) mengatakan bahwa orang yang memiliki kecerdasan emosi tinggi akan mampu memahami dirinya sendiri dan emosi orang lain. Dalam hal ini, kecerdasan interpersonal diperlukan untuk menjalin hubungan dalam sebuah tim yang berguna untuk melakukan pemecahan masalah.

Hipotesis 6 mengatakan bahwa kompetensi tidak berpengaruh positif terhadap kinerja audit internal melalui kematangan audit, hipotesis ditolak. Kematangan audit digunakan untuk mengukur sejauh mana peran seorang auditor dalam peningkatan efektivitas dan efisiensi kinerja audit internal. Kematangan audit pada perusahaan yang diteliti belum banyak melakukan analisa dan studi lapangan serta menentukan kontrol akan proses teknologi informasi. Menurut Asy et al. (2014) kesuluruhan proses penilaian kematangan audit adalah dengan analisa dan studi lapangan proses audit dan penentuan kontrol objektif proses teknologi informasi.

Hipotesis 7 mengatakan bahwa kompetensi tidak berpengaruh positif terhadap kinerja audit internal melalui aktivitas komputer audit, hipotesis ditolak. Alasan penolakan hipotesis ini adalah kurang lengkapnya penilaian risiko yang terkait dengan proses operasi kunci perusahaan, kurangnya audit komputer yang mengkonfirmasi kelengkapan data elektronik dan belum terdapat audit komputer secara baik. Menurut Suginam (2016) mengatakan bahwa auditor harus waspada terhadap penipuan dan mengambil langkah segera untuk menginvestigasi kecurigaannya. Audit internal menyediakan jasa seperti pemeriksaan, penilaian kontrol, kinerja, risiko dan tata kelola.

\section{KESIMPULAN DAN SARAN}

\section{Kesimpulan}

Kesimpulan dari penelitian ini adalah motivasi dari penelitian ini yaitu menambahkan variabel yaitu kematangan audit seperti yang direkomendasikan pada penelitian sebelumnya Wu et al., (2016). Berdasarkan pengujian dan penjelasan diatas dengan memberikan bukti empiris mengenai hubungan kompetensi, kemampuan pemecahan masalah dalam tim, kematangan audit dan aktivitas komputer audit terhadap kinerja audit internal. Hasil dari penelitian ini adalah sebagai berikut :

1. Hipotesis 1 yaitu terdukung atau terdapat pengaruh positif antara kompetensi terhadap kinerja audit internal. Artinya responden memiliki pengetahuan yang luas, keterampilan dalam mengolah informasi yang tinggi, memahami fungsi audit dalam proses audit dengan baik dan mampu melakukan proses audit dengan menggunakan komputer dengan baik.

2. Hipotesis 2 ditolak atau tidak terdapat pengaruh positif antara kemampuan pemecahan masalah dalam tim terhadap kinerja audit internal.

3. Hipotesis 3 ditolak atau tidak terdapat pengaruh positif antara kematangan audit terhadap kinerja audit internal. 
4. Hipotesis 4 ditolak atau tidak terdapat pengaruh positif antara aktivitas audit komputer terhadap kinerja audit internal.

5. Hipotesis 5 ditolak atau tidak terdapat hubungan intervening antara kompetensi terhadap kinerja audit internal melalui kemampuan pemecahan masalah dalam tim.

6. Hipotesis 6 ditolak atau tidak terdapat hubungan intervening antara kompetensi terhadap kinerja audit internal melalui kematangan audit.

7. Hipotesis 7 ditolak atau tidak terdapat hubungan intervening antara kompetensi terhadap kinerja audit internal melalui aktivitas audit komputer.

\section{Saran}

Saran bagi auditor internal

1. Bagi auditor internal disarankan untuk dapat meningkatkan kemampuan pemecahan masalah dalam tim karena dengan memecahkan masalah dalam tim dapat meningkatkan kinerja audit internal melalui pencapaian penemuan solusi secara cepat dan tepat.

2. Bagi auditor internal disarankan untuk dapat meningkatkan komputer audit dalam kegiatan audit karena dengan melakukan proses audit berbasis komputer dapat meningkatkan kinerja audit internal secara lebih efektif dan efisien.

3. Bagi auditor internal disarankan untuk dapat meningkatkan komputer audit dalam kegiatan audit karena dengan melakukan proses audit berbasis komputer dapat meningkatkan kinerja audit internal secara lebih efektif dan efisien.

\section{Keterbatasan}

Dalam penelitian ini, peneliti menghadapi beberapa keterbatasan, yaitu :

Pada variabel kemampuan masalah dalam tim, peneliti masih melakukan penilaian kinerja tim melalui persepsi individu dalam tim sehingga penilaian kinerja tim belum mewakili kinerja tim seharusnya karena masih dalam persepsi individu yang berbeda-beda. Peneliti selanjutnya dapat memberikan pertanyaan-pertanyaan kepada pimpinan perusahaan yang mengetahui kinerja tim audit pada perusahaan.

\section{DAFTAR PUSTAKA}

Andayani, W. 2008. Audit Internal (1st ed.). Yogyakarta: BPFE-Yogyakarta.

Asy', M. A., Prasetyono, A., dan B. Haryadi. 2014. Memetakan Satuan Pengawasan Intern Pada Pt X Dalam Kerangka Four Stage Model. Jaffa, 02(1), 23-38.

Economic, P. S. 2015. Pengaruh Kompetensi Terhadap Kinerja (Studi Kasus Guru SMAN 3 Tanjung Raja Kabupaten Ogan Ilir). Kosasih Zen, Wita Farla WK Fakultas Ekonomi Universitas Sriwijaya, (2000), 1-9.

Fauzi, M. 2012. Peningkatan Kerjasama. Mahfud Fauzi, FKIP, UMP, 2017 7 1, 7-27. Diunduh dari: http://repository.ump.ac.id/1123/3/BAB II.pdf

Fitriastuti. 2013. Pengaruh Kecerdasan Emosional, Komitmen Organisasional Dan Organizational Citizenship Behavior Terhadap Kinerja Karyawan. JurnaL Dinamika Manajemen, 4(2), 184-191. 
Hartono, J. 2013. Metodologi Penelitian Bisnis, Salah Kaprah dan Pengalaman Pengalaman (5th ed.). Yogyakarta: BPFE-Yogyakarta.

Mermod, A., \& Sungun, G. 2013. Internal Audit Positioning - Four Stage Model. Journal of Business Economics \& Finance, 2(1), 65-89.

Rifai, A. 2015. Partial Least Square-Structural Equation Modeling ( Pls-Sem ) Untuk Mengukur Ekspektasi Penggunaan Repositori Lembaga ( Pilot Studi Di Uin Syarif Hidayatullah Jakarta ). Al-Maktabh, 14, 56-65.

Suginam. 2016. Pengaruh Peran Audit Internal Terhadap Pencegahan Fraud ( Studi Kasus Pada PT . Tolan Tiga Indonesia ). Pelita Informatika Budi Darma, XV(1), 23-31.

Sujana, E. 2012. Pengaruh Kompetensi, Motivasi, Kesesuaian Peran Dan Komitmen Organisasi Terhadap Kinerja Auditor Internal Inspektorat Pemerintah Kabupaten (Studi Pada Kantor Inspektorat Kabupaten Badung Dan Buleleng). Jurnal Ilmiah Akuntansi Dan Humanika, 2(1), 1-27.

Uttam, B., Kumar, R. A., dan Sujoy, D. 2014. Audit Maturity Model. 155-161. Diunduh dari : https://arxiv.org/abs/1401.0137

Wu, T. H., Huang, S. M., Huang, S. Y., and Yen, D. C. 2016. The effect of competencies, team problem-solving ability, and computer audit activity on internal audit performance. Information Systems Frontiers, 1-16. 